\title{
To balance or not to balance budget?
} A proposed amendment to the US Constitution requiring a balanced budget could cause great harm to fundamental
research as well as to other social programmes on which the future of the United States now rests.

THE notion that the US government should spend no more than it receives in taxes and other income is perennially beguiling. It accords with the supposedly frugal housekeeping habits of the Founding Fathers. It would make the US federal deficit vanish at a stroke. And, by specifying how fiscal shortfalls should be bridged, it would rid members of Congress of the need for unpopular decisions on spending programmes. What can be wrong with such a recipe? Plenty.

So much should be plain from the past two weeks of debate in the US Senate. The present version of the proposition would eliminate the deficit and balance the federal budget by 2001. Its chief sponsor and advocate is Senator Paul Simon (Republican, Illinois), who is carrying the torch for-an idea that was endorsed by the two previous (Republican) presidents, Ronald Reagan and George Bush. But nobody has said just which programmes would be eliminated and which taxes raised to bring federal revenues and expenditures into equilibrium.

That, no doubt, is why the Senate is making heavy weather of the plan. Those who favour the amendment talk about taxing the rich and cutting spending on instruments of war. Those opposed cite the end of Social Security as the elderly know it and predict that, were another flood to drown the midwest, as last summer, there would be no money to rebuild the nation's breadbasket. But all of that is mere hyperbole that begs the real issue, which is this: can the United States realistically contemplate vastly higher taxes on the middle class (not just the wealthy) and a genuine limit on what is called discretionary (as distinct from mandatory) spending on education, health care and scientific research?

The answer, plainly, is "NO". It is not in the national interest to tear down the very programmes that US society most needs in order to meet the intellectual and competitive challenges of the next century. Of course, there are ways to get rid of pork-barrel spending on useless projects that serve the special interests of members of Congress wanting to appeal to their hometown voters, but that would hardly be enough to balance the budget. And even the budget-balancers themselves have drafted provisions that would allow Congress to unbalance the budget again any time threefifths of the members could be persuaded to vote an exception to the rules. But that exemption procedure is a recipe for a tough political battle on every case. The spoils would probably go to the most appealing cases: the victims of floods rather than physicists put out of work by reductions in federal support, for instance.
But the balanced-budget fervour is not lightly written off. The vote, which is about to come up in the Senate, is by no means certain. And there lies the rub. President Bill Clinton has made "investment" the buzzword of his administration. Selective spending on science and technology is indeed a genuine investment in future prosperity. But it is also one of the areas most vulnerable to a balanced budget amendment, no matter what its final permutations. The president asked for increases for science in his budget request for fiscal year 1995 (starting on 1 October 1994). But if a balanced budget is written into the Constitution, such increases would not be seen again. The research community, usually not exercised about spending issues in the abstract, should pay attention this time.

\section{Imanishi-Kari still in limbo}

A finding is needed in a case that has been lingering since 1987. Justice delayed is justice denied.

IT is seven years since the US National Institutes of Health (NIH) began their investigation of alleged fraud by Thereza Imanishi-Kari, the Tufts University researcher who was one of the authors of a now notorious paper on immunoglobulin gene expression (Cell 45, 247-259; 1986). The now-defunct NIH Office of Scientific Integrity (OSI) found her guilty of fabricating data and said so, in a draft document leaked to the press before Imanishi-Kari or her attorney could rebut the OSI's conclusions. Nothing much has happened since.

Of course, in 1989 the world all but found her guilty after a well-publicized hearing by Representative John Dingell (Democrat, Michigan), who called the Secret Service to give dramatic forensic evidence supposedly showing that Imanishi-Kari forged tapes from radioimmunoassays. She was not then and has not since been able to present experts who might challenge the Secret Service. The supposition of her guilt was also strengthened when the US federal attorney's office agreed to look into the case with an eye to criminal indictment. When the federal attorney dropped the case, the implication was that Imanishi-Kari was guilty, but that immunology is too intricate for her research to have been intelligible to a jury. Throughout this period, ImanishiKari has been denied the right to NIH grants and deprived of any meaningful opportunity to win tenure. And, for that, time is running out. 